\section{THE LAO-SPEAKING NYO IN BANTEAY MEANCHEY PROVINCE OF CAMBODIA}

\section{Thananan Trongdee ${ }^{1}$}

\begin{abstract}
There are some researches indicating the presence of Tai Yor or Lao Nyo or Nyo speakers in the Aranyaprathet district, $\mathrm{Sa}$ Keaw province of Thailand and in Banteay Meanchey province of Cambodia. This is surprising because as it is generally understood the Nyo people are predominantly located in Tha Uthen district, Nakhon Phanom province and in the Kantharawichai district, Maha Sarakham province. In order to investigate this discrepancy in 2012 the Lao Nyo was studied by the author in Banteay Meanchey province and data were gathered on the phonological system and basic words of the so called Lao Nyo dialect. The objectives of this paper are first to prove that the Lao Nyo dialect in Banteay Meanchey is neither Nyo nor Yo, and secondly to investigate some of the reasons underlying the identification of this Tai dialect as Lao Nyo. There are four sets of evidence presented here 1) a comparison of the tone boxes between Nyo, Yo, Lao Nyo and Lao; 2) a comparison of the development of proto Tai *aï,*eï,*ö in these dialects; 3) a comparison of the development of proto Tai $* k w,{ }^{*} k h w, * x w, * s w$ in these dialects; and 4) a comparison of the lexical items found only in Nyo. The results are 1) the tone box of Lao Nyo is different from both
\end{abstract}

\footnotetext{
${ }^{1}$ Assistant Professor of Linguistics, Faculty of Humanities and Social Sciences, Mahasarakham University, Maha Sarakham, Thailand.
}

Nyo and Yo but similar to Lao; 2) proto Tai *ai, *eï,*oi become -aj in Lao Nyo, Lao and Yo but become -a: in Nyo; 3) proto Tai *kw, *khw, *xw, * sw become $k w$, $k h w, k h w, k h w$ in Yo but become $k, k h, k h$, $k h$ in Nyo, Lao Nyo and Lao; and 4) the lexical items which are found only in Nyo cannot be found in Lao Nyo and Lao. Based on these four sets of evidence it can be concluded that Lao Nyo in Banteay Meanchey is neither Nyo nor Yo but is instead a dialect of Lao. The explanation proposed to account for the identification of this Lao dialect as Nyo or Lao Nyo is that some tone shapes in Nyo and Lao Nyo are very similar and some are even identical to the tone shapes in Nyo. This is likely to explain why these Lao speakers tend to identify themselves as Nyo or Lao Nyo.

\section{Introduction}

The suggestion that there are Nyo speakers in the southeastern part of Thailand and in the northwestern part of Cambodia is somewhat surprising. These places are very far from the Nyo's homeland in Khammouan village, in the Khamkeut district of Bolikhamxay province in Lao PDR and quite far from their Nyo relatives in Tha Uthen district of Nakhon Phanom province and Nyo in the Kantharawichai district of Maha Sarakham province in the northeastern part of Thailand. ${ }^{2}$ The Nyo language in the southeastern part of Thailand (i.e. in the Aranyaprathet district of Sa Keaw province) which is related to Nyo in Cambodia has been described by Srivisithkul (1986) and Nilchinda (1989). The Nyo in the Banteay Meanchey

\footnotetext{
2 The places where Nyo people live in Laos were indicated in Chamberlain (1984:75) and their locations in Nakhon Phanom were indicated in Koowatthanasiri (1981:30).
} 
province, which is located in the northwestern part of Cambodia, was mentioned in Schliesinger (2011a). He stated,

The recently established new province of Banteay Meanchey of northwestern Cambodia, an area that was a part of Battambang province for many centuries, is populated by at least five Tai groups: Phuan, Lao Vientiane, Tai Yor $^{3}$, Khorat Thai and Lao-Thai Isan. They live in scattered villages in the fertile plains in the western part of the province, and many work vast plots of rice paddy fields. During the nineteenth century, the ancestors of Phuan, Lao Vientiane and Tai Yor were captured by the Siamese army in their original habitat of northern and central Laos, and were resettled in Battambang province which belonged to Siam at that time. The Khorat Thai migrated for economic reasons in the $19^{\text {th }}$ and early $20^{\text {th }}$ centuries to their present habitat of Mongkol Borei district. The few Lao-Thai Isan people are newcomers who settled in recent years in the area for reasons of marriage or to establish new business. (2011a: 250)

Schliesinger (2011a: 316) estimated that there are 10,000-15,000 Lao Nyo speakers in Banteay Meanchey province.

To eliminate my skepticism of the presence of Tai Yor's living in Cambodia, I conducted some fieldwork in Banteay Meanchey in 2012. I found that these people like to call themselves Lao Nyo

\footnotetext{
${ }^{3}$ Schliesinger (2011a: 316 ) mentioned other names of Tai Yor as Tai Nyo, Nyo, Lao Yor etc.
}

(la: ${ }^{33}$ nว: $\left.{ }^{442}\right)$ or Nyo $\left(\right.$ nว: $\left.{ }^{442}\right)$ but based on linguistic evidence they are in fact speakers of a Lao dialect. For convenience I will refer to them as Lao Nyo in this paper.

\section{Habitats of Lao Nyo in Cambodia and Thailand}

According to Schliesinger (2011b: 106) the Lao Nyo live in five villages, but, during interviews for this paper, the headman of Aunloung Svay Chas village said that there are Lao Nyo in nine villages in the $\mathrm{Ou}$ Chrov district, the Banteay Meanchey province i.e. Koub Thom, Dong Aranh, Aunloung Svay Chas, Aun Loung Svay Thwey, Koub Touch, Koub Cherng, Koub Thboung, Khai Dorn and Sery Pheap and some live in the Srei Sophone district i.e. Phnum Bak village in Tuek Thla commune and Ambel village in $\mathrm{Ou}$ Ambel communes, and there are Lao Nyo in five villages in the Bor Vil district, Battambang province i.e. Makreu, Salor Klaen, Phum Leau, Prey Kapos and Phum Koub. He also mentioned there are Lao Nyo in the Aranyaprathet district, Sa Kaew province of Thailand.

It was mentioned in Srivisithkul (1986: 47) that the Lao Nyo in the Aranyaprathet district live in Klongnamsai, Muangphai, Phansuk, Thakham sub-districts and in Aranyaprathet municipality. The locations of the Aranyaprathet district of Thailand and the Banteay Meanchey province of Cambodia are shown in Map 1. 


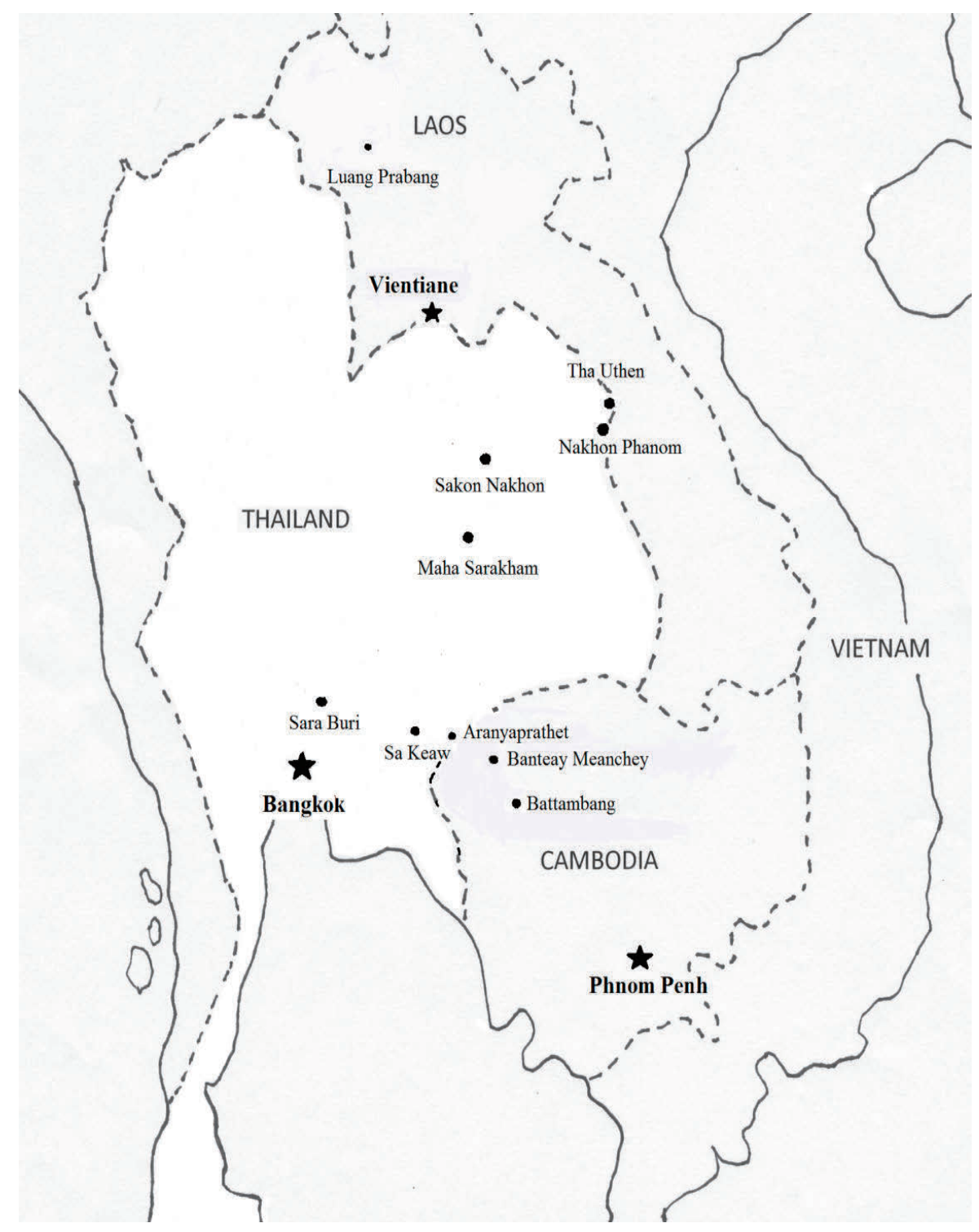

Map 1 The Locations of Aranyaprathet of Thailand and the Banteay Meanchey province of Cambodia 


\section{Objectives}

The objectives of this paper are first to prove that the Lao Nyo speakers do not speak either Nyo or Yo but in fact speak Lao and secondly to propose some explanations as to why these speakers tend to identify themselves as Nyo.

\section{Gathering Data of Lao Nyo}

To get the linguistic data of Lao Nyo in Cambodia a tone checklist of 60 items from Gedney (1972), a word list of 1,140 items from $\mathrm{Li}$ (1977), and a phoneme checklist complied by the researcher were used for eliciting data from a 70 year old male speaker in Dong Aranh village, and a 45 year old village headman from Aunloung Svay Chas village in the $\mathrm{Ou}$ Chrov district of Banteay Meanchey province, Cambodia. The checklist for tones and the checklist for phoneme inventory of consonants and vowels were transcribed. The pitch of tones was recorded on a digital recorder. A Praat program was used to analyze their acoustic characteristics. The phoneme inventory of Aunloung Svay Chas dialect is shown in the Appendix.

The linguistic data of Lao Nyo in Klongnamsai village, Aranyaprathet district, Sa Keaw province were gathered from Srivisithkul (1986) and Nilchinda (1989).

\section{Comparison of Nyo, Yo, Lao Nyo and Lao}

To prove that Lao Nyo is neither Nyo nor Yo, the most salient features that occur in Nyo and Yo but which cannot be found in Lao Nyo and Lao have been selected. There are four points of linguistic evidence to be compared: 1) - the developments of their tone boxes; 2) - the vowels developed from proto Tai *əï,*eï,*oï ; 3) - the consonants developed from proto Tai $*_{\mathrm{kw}},{ }^{*} \mathrm{khw},{ }^{*} \mathrm{xw}{ }^{*}{ }_{\mathrm{\gamma w}}$; and 4) - the lexical items found in Nyo that cannot be found in Lao Nyo and Lao.

\section{Tone Boxes}

In order to assess whether that the tone box of Lao Nyo is a Lao tone system, the criteria proposed by Chamberlain (1975: 50) has been adopted.

Chamberlain used the changes of proto Tai consonants, tone split and tone merger as the criteria to classify Southwestern Tai (SWT) dialects into 4 groups as shown in Chart I.

According to Chamberlain's criteria the proto Tai voiced stops became voiceless unaspirated stops in the $\mathrm{P}$ group, and became voiceless aspirated stops in $\mathrm{PH}$ group. The split of *A in the $\mathrm{PH}$ group can be either $123-4,1-234$ or 1-23-4. The $\mathrm{PH}$ group is sub-divided depending on the splitting pattern of $* \mathrm{BCD}$ and the merger of the $\mathrm{B}$ and the DL column.

Another criterion pointed out in Tingsabadh (1982: 485) has also been adopted. Tingsabadh mentioned that the salient characteristics of tone merger in many Lao dialects is the merger of C1=DL123 and C234=DL4.

The tone box of Nyo in Tha Uthen village, Tha Uthen district, Nakhon Phanom province is from my own field study for this paper as shown in Figure 1. Its tone split in A is 1-234, in BCD is 123-4 and tone merger is $\mathrm{B}=\mathrm{DL}$. Therefore, it is classified in the same group as Siamese, Phu Tai, Neau and Phuan. 


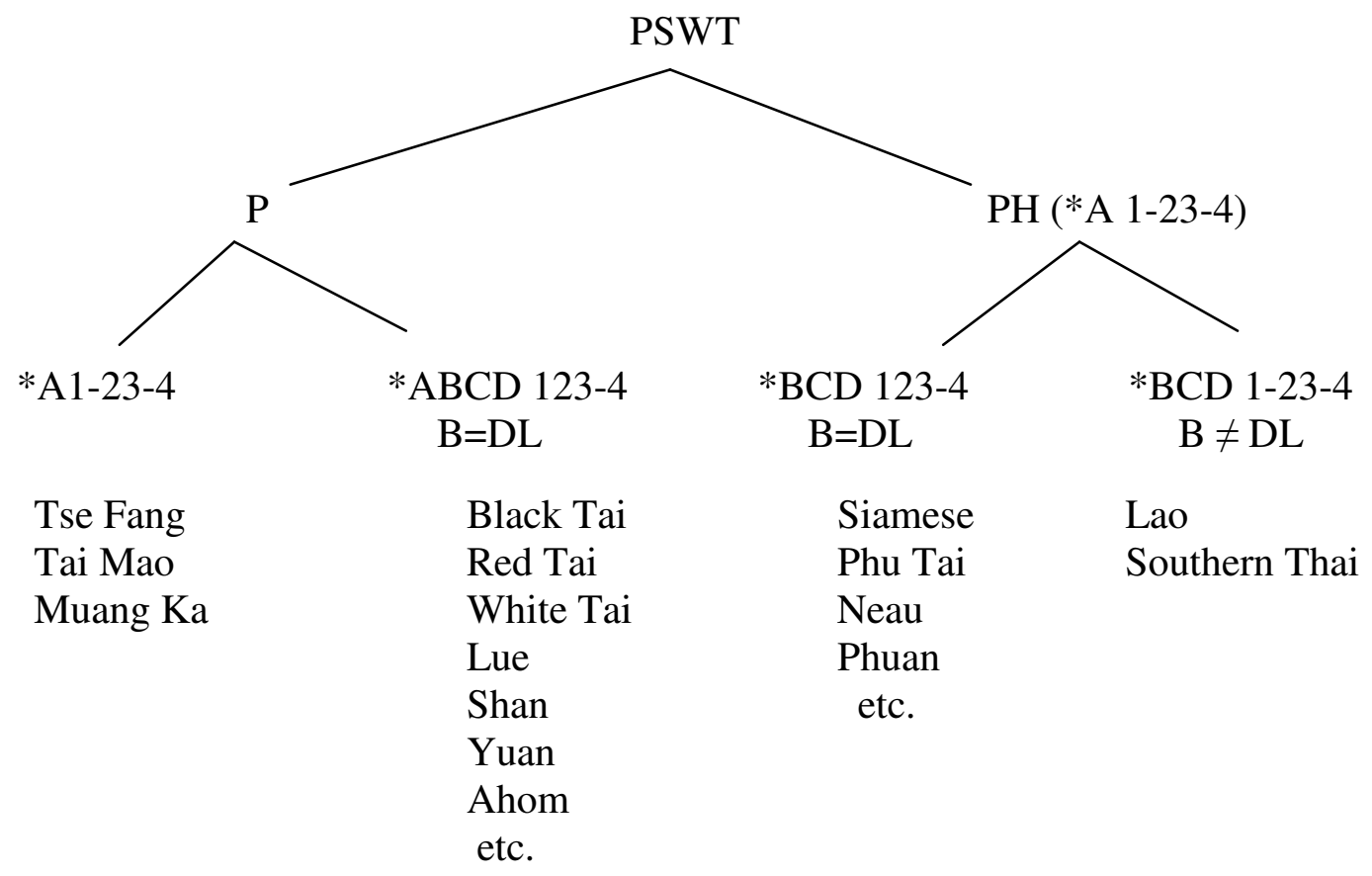

Chart 1 Classification of SWT dialects (Chamberlain 1975)

\begin{tabular}{|c|c|c|c|c|c|}
\hline & $\mathrm{A}$ & $\mathrm{B}$ & $\mathrm{C}$ & $\mathrm{DL}$ & $\mathrm{DS}$ \\
\hline 1 & 324 & 32 & $33 ?$ & 32 & 35 \\
\hline 2 & \multirow{3}{*}{24} & & & & \\
\cline { 1 - 3 } 3 & 24 & & & & \\
\cline { 1 - 5 } 4 & & 42 & $45 ?$ & 42 & 44 \\
\hline
\end{tabular}

Figure 1 Tone box of Nyo in Tha Uthen village, Nakhon Phanom

The tone box of Nyo in Tha Khonyang village, Kantharawichai district, Maha Sarakham province is from my own field study for this paper as shown in Figure 2. Its pattern of split or merger of proto-Tai tones is identical with the tone box of $\mathrm{Na}$ Kang Nyo mentioned in Chamberlain (1984: 72). Its tone split in A is 123-4, in $\mathrm{BCD}$ is $123-4$ and tone merger is $\mathrm{B}=\mathrm{DL}$. Therefore, it is classified in the same group as Siamese, Phu Tai, Neau and Phuan.

\begin{tabular}{|c|c|c|c|c|c|}
\hline & A & B & $\mathrm{C}$ & DL & DS \\
\hline 1 & \multirow[t]{3}{*}{24} & \multirow{4}{*}{32} & $33 ?$ & \multirow{4}{*}{32} & \multirow[t]{3}{*}{35} \\
\hline 2 & & & & & \\
\hline 3 & & & & & \\
\hline 4 & 35 & & $342 ?$ & & 33 \\
\hline
\end{tabular}

Figure 2 Tone box of Nyo in Tha Khonyang village, Maha Sarakham

The tone boxes of Sakon Nakhon Yo were studied thoroughly in Koowatthanasiri (1981). Their tone boxes are the same as Yo in Taw Ngoy village, Muang district, Sakon Nakhon province mentioned in Chamberlain (1984: 78) as shown in Figure 3. Its tone split in A is 123-4, in $\mathrm{BCD}$ is $1-23-4$ and tone mergers are $\mathrm{B}=\mathrm{DL}, \quad \mathrm{C} 1=\mathrm{DL} 123$ and $\mathrm{C} 234=\mathrm{DL} 4$. Therefore, it is classified in the same group as Lao and Southern Thai. 


\begin{tabular}{|c|c|c|c|c|c|}
\hline & $\mathrm{A}$ & B & $\mathrm{C}$ & DL & DS \\
\hline 1 & \multirow[t]{3}{*}{24} & \multirow[t]{3}{*}{31} & 31 & \multirow[t]{3}{*}{31} & \multirow[t]{3}{*}{35} \\
\hline 2 & & & & & \\
\hline 3 & & & 42 & & \\
\hline 4 & 45 & 42 & & 42 & 33 \\
\hline
\end{tabular}

Figure 3 Tone box of Yo in Taw Ngoy village, Sakon Nakhon (adapted from

Chamberlain 1984: 78)

The tone system of many Lao dialects were studied in Brown (1965) and Akharawatthanakun (2003). Vientiane Lao was classified as Pure Lao in the 1/1 subgroup (Akharawatthanakun 2003:196), as shown in Figure 4. The tone split in A is 1$23-4$, in $\mathrm{BCD}$ is $1-23-4$ and tone mergers are $\mathrm{B} \neq \mathrm{DL}, \mathrm{C} 1=\mathrm{DL} 123$ and C234=DL4. Therefore, it is classified in the same group as Lao and Southern Thai.

\begin{tabular}{|c|c|c|c|c|c|}
\hline & $\mathrm{A}$ & B & $\mathrm{C}$ & $\mathrm{DL}$ & DS \\
\hline 1 & 334 & \multirow{4}{*}{33} & $22 ?$ & \multirow[t]{3}{*}{$22 ?$} & \multirow[t]{3}{*}{434} \\
\hline 2 & 232 & & \multirow{3}{*}{$441 ?$} & & \\
\hline 3 & & & & & \\
\hline 4 & 343 & & & $441 ?$ & 44 \\
\hline
\end{tabular}

Figure 4 Tone box of Vientiane Lao (adapted from Akharawattanakun 2003)

The tone system of Luang Prabang Lao was classified as Pure Lao in the $1 / 2$ subgroup (Akharawatthanakun 2003: 208). Its tone box is shown as Figure 5. The tone split in A is 1-234, in BCD is 1-23-4 and tone mergers are $\mathrm{B} \neq \mathrm{DL}, \mathrm{C} 1=\mathrm{DL} 123$ and C234=DL4. Therefore, it is classified in the same group as Lao and Southern Thai.

\begin{tabular}{|c|c|c|c|c|c|}
\hline & $\mathrm{A}$ & B & $\mathrm{C}$ & $\mathrm{DL}$ & DS \\
\hline 1 & 523 & \multirow{4}{*}{31} & 42 & \multirow[t]{3}{*}{42} & \multirow[t]{3}{*}{22} \\
\hline 2 & \multirow{3}{*}{223} & & \multirow{3}{*}{232} & & \\
\hline 3 & & & & & \\
\hline 4 & & & & 232 & 32 \\
\hline
\end{tabular}

Figure 5 Tone box of Luang Prabang Lao (adapted from Akharawattanakun 2003)

The tone box of Lao Nyo in Aun Loung Svay Chas village, Ou Chrov district is from my own field study as shown in Figure 6. The tone split in $\mathrm{A}$ is $1-234$, in $\mathrm{BCD}$ is $1-23-4$ and tone mergers are $\mathrm{B} \neq$ DL, C1=DL123 and C234=DL4. Therefore, it is classified in the same group as Lao and Southern Thai.

\begin{tabular}{|c|c|c|c|c|c|}
\hline & $\mathrm{A}$ & B & $\mathrm{C}$ & $\mathrm{DL}$ & $\overline{D S}$ \\
\hline 1 & 24 & \multirow{4}{*}{32} & $42 ?$ & \multirow[t]{3}{*}{42} & \multirow[t]{3}{*}{35} \\
\hline 2 & \multirow{3}{*}{33} & & \multirow{3}{*}{ 44? } & & \\
\hline 3 & & & & & \\
\hline 4 & & & & 44 & 33 \\
\hline
\end{tabular}

Figure 6 Tone box of Lao Nyo in Aun Loung Svay Chas village, Cambodia

Based on Chamberlain's (1975) and Tingsabadh's (1982) criteria, Nyo in Tha Uthen and Tha Khonyang should be in $\mathrm{PH},{ }^{*} \mathrm{BCD} 123-4$ and $\mathrm{B}=\mathrm{DL}$ group but Yo in Sakon Nakhon, Lao in Vientiane, Lao in Luang Prabang and Lao Nyo in Cambodia should be in $\mathrm{PH}, * \mathrm{BCD} 1-23-4, \mathrm{~B} \neq \mathrm{DL}$ group with $\mathrm{C} 1=\mathrm{DL} 123$ and $\mathrm{C} 234=\mathrm{DL} 4$.

It is noticeable that the overall split and merger of tones in Lao Nyo are strikingly similar to those of Luang Prabang Lao. 
Vowels Developed from Proto Tai *əï, *eï, *oï

Cognate words which have the vowels developed from proto *əï,*eï and *oï (Li 1977) became [ə:] in Tha Uthen and Tha Khonyang Nyo but became [aj] in Yo, Lao Nyo, Vientiane Lao and became [ащ] in
Luang Prabang Lao. The cognate words in Tha Uthen Nyo and Sakon Nakhon Yo are gathered from Nilchinda (1989) and Jodking (1980), the cognate words in Vientiane Lao are gathered from Viravongs (2006), and the cognate words in Luang Prabang Lao are elicited from a graduate Lao student studying in Mahasarakham University.

\section{Proto Tai *ə̈̈}

Th.U. Nyo

bə: ${ }^{24}$

tə: $:^{24}$

tə: ${ }^{33}$ ?

nə: ${ }^{24}$

$\mathrm{kə} \cdot{ }^{33}$ ?

sə: ${ }^{324}$

hə: ${ }^{33}$ ?
S.K. Yo

baj $^{24}$

taj $^{24}$

taj $^{42}$

naj $^{45}$

kaj $^{42}$

saj $^{24}$

haj $^{31}$

\section{Lao Nyo}

baj $^{33}$

taj $^{33}$

taj $^{44}$ ?

naj $^{33}$

kaj $^{44}$ ?

saj $^{24}$

haj $^{42 ?}$
V.T. Lao

baj $^{24}$

taj $^{24}$

taj $^{31 \text { ? }}$

naj $^{34}$

$\mathrm{kaj}^{31}$ ?

saj $^{24}$

haj $^{21 ?}$

\section{L.B. Lao}

baum $^{24}$

$\operatorname{taw}^{24}$

$\operatorname{taw}^{35}$ ?

naw $^{24}$

kaw $^{35}$

sau $^{423}$

haw $^{43}$ ?
Gloss

'leaf'

'gizzards'

'under'

'inside'

'near'

'clear'

'to give'

Proto Tai *eï

$\begin{array}{llllll}\text { Th.U. Nyo } & \text { S.K.Yo } & \text { Lao Nyo } & \text { V.T. Lao } & \text { L.B. Lao } & \text { Gloss } \\ \text { cə: }^{24} & \text { caj }^{24} & \text { caj }^{33} & \text { caj }^{24} & \text { caw }^{24} & \text { 'breath' } \\ \text { khə: }^{42} & \text { khaj }^{42} & \text { khaj }^{32} & \text { khaj }^{33} & \text { khaw }^{33} & \text { 'swollen' }\end{array}$

\section{Proto Tai *oï}

$\begin{array}{llllll}\text { Th.U. Nyo } & \text { S.K.Yo } & \text { Lao Nyo } & \text { V.T. Lao } & \text { L.B. Lao } & \text { Gloss } \\ \text { mə: }^{32} & \text { maj }^{31} & \text { maj }^{32} & \text { maj }^{33} & \text { maw }^{33} & \text { 'new' } \\ \text { sə: }^{32} & \text { saj }^{31} & \text { saj }^{32} & \text { saj }^{33} & \text { sau }^{33} & \text { 'to put in' }\end{array}$

It is apparent that the vowel correspondences in the cognate words in Tha Uthen Nyo are completely different from the vowel correspondences in Yo, Lao Nyo, Vientiane Lao and Luang Prabang Lao.

\section{Consonants developed from Proto-Tai *kw, *khw *xw, *yw}

Proto-Tai *kw, *khw, *xw and * ${ }^{\mathrm{xw}}$ became kw-, khw-, khw- and khw- respectively in Sakon Nakhon Yo but became k-, kh-, kh- and kh- in Tha Uthen Nyo, Lao Nyo Vientiane Lao and Luang Prabang Lao. 
Proto-Tai *kw

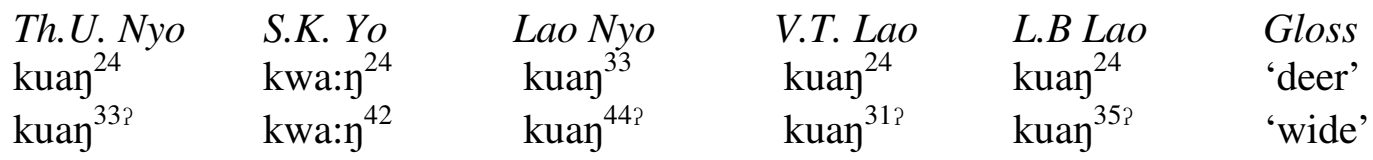

Proto-Tai *khw

$\begin{array}{llllll}\text { Th.U. Nyo } & \text { S.K.Yo } & \begin{array}{c}\text { Lao Nyo } \\ \text { khua }^{24}\end{array} & \begin{array}{c}\text { V.T. Lao } \\ \text { khua }^{24}\end{array} & \begin{array}{l}\text { L.B Lao } \\ \text { khua }^{423}\end{array} & \begin{array}{l}\text { Gloss } \\ \text { 'right side' }\end{array} \\ \text { khwa: }^{24} & \text { shua }^{24} & \text {, }\end{array}$

Proto-Tai *xw

$\begin{array}{llllll}\text { Th.U. Nyo } & \text { S.K.Yo } & \text { Lao Nyo } & \text { V.T. Lao } & \text { L.B Lao } & \text { Gloss } \\ \text { khuan }^{324} & \text { khwan }^{24} & \text { khuan }^{24} & \operatorname{khuan}^{24} & \operatorname{khuan}^{423} & \text { 'spirit' } \\ \text { khuan }^{324} & \text { khwa:n }^{24} & \operatorname{khuan}^{24} & \operatorname{khuan}^{24} & \text { khuan }^{423} & \text { 'axe' }\end{array}$

Proto-Tai *yw

\begin{tabular}{|c|c|c|c|c|c|}
\hline & $\begin{array}{l}S . K . Y o \\
\text { khwa.j4 }\end{array}$ & $\begin{array}{r}\text { Lao Nyo } \\
\mathrm{khuai}^{3}\end{array}$ & V.T. Lao & $\begin{array}{l}\text { L. B Lao } \\
\text { Khuai }^{24}\end{array}$ & $\begin{array}{l}\text { Gloss } \\
\text { 'buffalo' }\end{array}$ \\
\hline $\operatorname{tuan}^{24}$ & khwan $^{45}$ & khuan $^{33}$ & khuan $^{34}$ & khuan $^{24}$ & 'smoke' \\
\hline
\end{tabular}

Up to this point, based on the phonological development from Proto-Tai, it can be shown confidently that Lao Nyo is neither Nyo, or Yo.

\section{Lexical Difference}

There are two words in Tha Uthen Nyo which cannot be found in Sakon Nakhon Yo, Lao Nyo and Luang Prabang Lao.

\begin{tabular}{|c|c|c|c|c|}
\hline $\begin{array}{l}\text { Th.U. Nyo } \\
\text { hə: } \\
\text { ha: }:^{32}\end{array}$ & $\begin{array}{l}\text { S.K. Yo } \\
\operatorname{m\varepsilon }_{\text {nup }^{43}}^{45} \eta^{42} \eta^{42} \eta^{42}\end{array}$ & $\begin{array}{l}\text { Lao Nyo } \\
\text { lu:k }{ }^{44} \text { na:m } \\
\text { nup }^{33}\end{array}$ & $\begin{array}{l}\text { L.P. Lao } \\
\text { khaj }^{33} \text { nup }^{24} \\
\text { nup }^{33}\end{array}$ & $\begin{array}{l}\text { Gloss } \\
\text { 'mosquito larva' } \\
\text { '(vegetable)be } \\
\text { softened' }\end{array}$ \\
\hline
\end{tabular}

\section{Explanation for the ethnonym Lao Nyo}

Based on the evidence shown above it can be concluded that the Lao Nyo are neither Nyo nor Yo, they speak a dialect of Lao, which begs the question: why does this group use the ethnonym of as Lao Nyo or Nyo? Is it possible that in former times their ancestors spoke Nyo, and then they shifted their language to Lao because it had been influenced by Lao language in this area? This is not probable because it is estimated in Schliesinger (2011a: 316) that there are only 700 Lao speakers, but there are 10,000-15,000 Lao Nyo speakers in Banteay Meanchey province.

In a discussion of the terms Nho and Yo, Chamberlain states: 
This ethnonym or its non-nasalized, fricative, or affricated variants, is found to range from Thanh-Hoa through NgêAn, Khammouan, Nakhon Phanom, and Sakon Nakhon. The Yo (dzoo) of Muang Sen belongs to the $\mathrm{P}$ group but $\mathrm{PT} / * \mathrm{kh} / \mathrm{has}$ changed to /h/ as in Phu Tai and some Northern Branch languages. The Yo (nhoo) of Sakon Nakhon has a Lao tone system, with only four tones on smooth syllables as in Khorat and Kaleung. The Nho (nhoo) of Tha Uthen in Nakhon Phanom and the Nho of Na Kang in Khammouan are both $\mathrm{PH}$ group languages, but with somewhat different tone systems. The Yo (Yo) mentioned by Robequain (1929) from Thanh-Hoa would appear to be yet another different dialect judging from the vocabulary items which he cites. Finally, the Muang Sen informant stated that what he calls Yo is also to be found in Cura-Rao, Khe Bo, Con Cương, situated along the Sông $\mathrm{Ca}$ river, and in Qui Chau. The origin of the term is still a mystery as it could conceivably come from a wide variety of sources. (Chamberlain 1984: 75)

In the opinion of the researcher, the term Lao Nyo or Nyo, which has been adopted by the Lao in Aranyaprathet district and in Ou Chrov district, could have been the exonym which outsiders used to name them, and later they adopted this name as their own ethnonym. It is probable that those outsiders or the Thai speakers in the area recognized that the Lao Nyo accent is different from Lao (Isan Thai) but is similar to the Nyo accent, therefore, they called this Lao dialect Lao Nyo.

Consider the tone boxes of Tha Uthen Nyo and Lao Nyo again in Figure 7 and 8.

\begin{tabular}{|c|c|c|c|c|c|}
\hline & $\mathrm{A}$ & $\mathrm{B}$ & $\mathrm{C}$ & $\mathrm{DL}$ & $\mathrm{DS}$ \\
\hline 1 & 324 & 32 & $33 ?$ & 32 & 35 \\
\cline { 1 - 1 } 2 & \multirow{3}{*}{24} & & & & \\
\cline { 1 - 4 } 3 & 24 & & & & \\
\cline { 1 - 4 } 4 & & 42 & $45 ?$ & 42 & 44 \\
\hline
\end{tabular}

Figure 7 Tone box of Nyo in Tha Uthen village, Nakhon Phanom

\begin{tabular}{|c|c|c|c|c|c|}
\hline & $\mathrm{A}$ & B & $\mathrm{C}$ & DL & DS \\
\hline 1 & 24 & \multirow{4}{*}{32} & $42 ?$ & \multirow[t]{3}{*}{42} & \multirow[t]{3}{*}{35} \\
\hline 2 & \multirow{3}{*}{33} & & \multirow{3}{*}{$44 ?$} & & \\
\hline 3 & & & & & \\
\hline 4 & & & & 44 & 33 \\
\hline
\end{tabular}

Figure 8 Tone box of Lao Nyo in Aun Loung Svay Chas village, Cambodia

Although the patterns of the split and merger of tones are different between Lao Nyo and Tha Uthen Nyo; some tone shapes are strikingly similar and some are even identical. The tone shape in the B column of both Tha Uthen Nyo and Lao Nyo is mid-falling. The tone shape in the DL column of both Tha Uthen Nyo and Lao Nyo is falling but slightly different at the beginning of the tone. The tone shapes in DS column of both Tha Uthen Nyo and Lao Nyo are almost identical. From this evidence it could be hypothesized that the similarity of these tone shapes might cause outsiders to believe that this language is a dialect of Nyo.

It is noteworthy here to mention the case of the Lao dialects in the Muang district, in Sakon Nakhon province and in the Muang district, in Nakhon Phanom province. The Lao dialects in these two places are also called Nyo or Yo by other Isan Thais and there are some theses which treat Nyo and Yo as the same group (Koowatthanasiri 1981, Nilchinda1989, Akharawatthanakun 1998). Chamberlain 
(1984: 82) may have been the first one to indicate explicitly that "The Yo of Sakon Nakhon speak a Lao dialect, unlike the Neua-Phuan Yo (Nho) of Tha Uthen and Khammouan, or P-Group Yo of Muang Sen."

It is apparent that there are some tone shapes in Sakon Nakhon Yo, especially the falling tones in $\mathrm{B}, \mathrm{DL}$ and the tones in the DS column which are similar to Tha Uthen Nyo. It may be the answer as to why Isan Thai people think that Nyo and Yo are the same dialect. The tone boxes of Sakon Nakhon Yo are shown again in Figure 9.

\begin{tabular}{|c|c|c|c|c|c|}
\hline & $\mathrm{A}$ & $\mathrm{B}$ & $\mathrm{C}$ & $\mathrm{DL}$ & $\overline{\mathrm{DS}}$ \\
\hline 1 & \multirow[t]{3}{*}{24} & \multirow[t]{3}{*}{31} & 31 & \multirow[t]{3}{*}{31} & \multirow[t]{3}{*}{35} \\
\hline 2 & & & \multirow{3}{*}{42} & & \\
\hline 3 & & & & & \\
\hline 4 & 45 & 42 & & 42 & 33 \\
\hline
\end{tabular}

Figure 9 Tone box of Yo in Taw Ngoy village, Sakon Nakhon (adapted from

Chamberlain 1984: 78)

There is one more case - the Nyo of Tha Sala village, Tha Khlo sub-district, Keangkhoi district, Sara Buri province. The tone box of Tha Sala Nyo mentioned in Akharawatthanakun (2003: 124) as shown in Figure 10 is similar to the tone box of Luang Prabang Lao i.e. A1-234, BCD1-23-4, $\mathrm{B} \neq \mathrm{DL}, \quad \mathrm{C} 1=\mathrm{DL} 123$ and C234=DL4.

\begin{tabular}{|c|c|c|c|c|c|}
\hline & $\mathrm{A}$ & B & $\mathrm{C}$ & $\mathrm{DL}$ & DS \\
\hline 1 & 324 & \multirow{4}{*}{433} & 554 & \multirow[t]{3}{*}{554} & 323 \\
\hline 2 & \multirow{3}{*}{232} & & \multirow{3}{*}{34} & & \\
\hline 3 & & & & & \\
\hline 4 & & & & 44 & 443 \\
\hline
\end{tabular}

Figure 10 Tone box of Nyo in Tha Sala, Sara Buri (adapted from

Akharawatthanakun 2003)

However, it is not possible to postulate whether Nyo in Tha Sala is Lao, Nyo or Yo since there is lack of other evidence, especially the development of proto-Tai *əї, *eї, *oï, and *kw, *khw, *xw, * and some lexical items in this dialect.

\section{Conclusion}

Based on the evidence of the development of tone system, vowel diphthongs, consonant clusters and vocabulary, the Lao Nyo in Ou Chrov district, Banteay Meanchey province, Cambodia is neither Nyo nor Yo but is actually Lao. This paper proposes that the ethnonym of the Lao Nyo was its exonym, given to the group by outsiders or Thai speakers in the area. Later the Lao speakers in Banteay Meanchey have adopted this exonym to be their own autonym.

\section{Acknowledgment}

I am greatly indebted to the people in Dong Aranh and Aun Loung Svay Chas villages, Banteay Meanchey province, Cambodia for their help. Without them this paper would have been impossible.

\section{References}

Akharawattanakun, Phinnarat. 1998. A Comparative Study of the Tonal System in the Speech of the "Lao" the "Nyo", 
and the "Phutai" in That Phanom District, Nakhon Phanom Province. M.A. Thesis, Chulalongkorn University.

Akharawattanakun, Phinnarat. 2003. Tone Change: A Case Study of The Lao Language. Ph.D. Dissertation, Chulalongkorn University.

Brown, J. Marvin. 1965. From Ancient Thai to Modern Dialects. Bangkok: Social Science Association Press.

Chamberlain, James R. 1975. A New Look at the History and Classification of the Tai Languages. In Studies in Tai Linguistics in Honor of William J. Gedney, edited by Jimmy G. Harris \& James R. Chamberlain, pp.49-66. Bangkok: Central Institute of English Language.

Chamberlain, James R. 1984. The Tai Dialects of Khammouan Province: Their Diversity and Origins. In Science of Language, Vol. 4, edited by Sudaporn Luksaneeyanawin, pp. 62-95. Bangkok: Department of Linguistics, Faculty of Arts, Chulalongkorn University.

Gedney, William J. 1972. A Checklist for Determining Tones in Tai Dialects. In Studies in Linguistics in Honor of George L. Trager, edited by M. Estellie Smith, pp.423-437. The Hague:

Mouton.

Jodking, Wutichai. 1980. Some Characteristics of the $/ \mathrm{ns}^{4} /$ Language at Sakon Nakhon. M.A. Thesis, Mahidol University.
Koowatthanasiri, Kanjana. 1981. The Tones of Nyo. M.A. Thesis, Chulalongkorn University

Li, Fangkuei. 1977. A Handbook of Comparative Tai. (Oceanic Linguistics Special Publication no. 15). Honolulu: The University Press of Hawaii.

Nilchinda, Nantaporn. 1989. A Lexical Study of Nyo Spoken in Sakon Nakhon, Nakhon Phanom and Prachin

Buri. M.A. Thesis, Silpakorn University.

Schliesinger, Joachim. 2011a. Ethnic Groups of Cambodia, Volume I. Introduction and Overview. Bangkok: White Lotus Press.

Schliessinger, Joachim. 2011b. Ethnic Groups of Cambodia, Volume 3. Profile of Austro-Thai- and Sinitic-Speaking Peoples. Bangkok: White Lotus Press.

Srivisithkul, Sriphin. 1986. Some Characteristics of the Yo Dialect at Klongnamsai Sub- district, Aranyaprathet District, Prachin Buri Province. M.A. Thesis, Silpakorn University.

Tingsabadh, Kalaya. M.R. 1982. Languages and Dialects in Thailand. in Thai 3 :Linguistics for Teacher. Unit 15. Bangkok : Sukhothaithammathiraj University. pp. 477-479.

Viravongs, Sila. 2006. Dictionary of Lao Language (New Edition). Vientiane: Ministry of Education. (In Lao) 


\section{Appendix}

\section{Phoneme Inventory of Aun Loung Svay Chas Lao}

The phoneme inventory of Lao in Aun Loung Svay Chas village, Cambodia comprises of tones, consonants and vowels. Syllable structure is simple: $\mathrm{CV}^{\mathrm{T}}, \mathrm{CVV}^{\mathrm{T}}, \mathrm{CVC}^{\mathrm{T}}, \mathrm{CV}: \mathrm{C}^{\mathrm{T}}$ and CVVC $^{\mathrm{T}}$.

Tones. There are five tones. The tone shapes were based on my auditory judgment first and then reconfirmed by using the Praat program to analyze their fundamental frequencies.

Tone 1 represents a low-rising pitch (24).

$\begin{array}{ll}\mathrm{kha}^{24} & \text { 'leg' } \\ \mathrm{hu}:{ }^{24} & \text { 'ear' } \\ \mathrm{ma}:{ }^{24} & \text { 'dog', }\end{array}$

When this tone occurs in a checked syllable it becomes a mid-rising pitch.

$\begin{array}{ll}\mathrm{khat}^{35} & \text { 'to shut' } \\ \mathrm{mat}^{35} & \text { 'flea' } \\ \mathrm{kat}^{35} & \text { 'to bite' } \\ \text { bet }^{35} & \text { 'fish hook' }\end{array}$

Tone 2 represents a mid level pitch (33) slightly falling at the end.

$\begin{array}{ll}\mathrm{kha}:{ }^{33} & \text { 'thatch grass' } \\ \mathrm{ka}:{ }^{33} & \text { 'crow' } \\ \mathrm{ma}:{ }^{33} & \text { 'to come' }\end{array}$

This tone also occurs in a checked syllable as in the following words.

$\begin{array}{ll}\text { khat }^{33} & \text { 'to stop bleeding' } \\ \text { nok }^{33} & \text { 'bird' } \\ \text { mot }^{33} & \text { 'ant' }\end{array}$

Tone 3 represents a mid-falling pitch (32).
$\mathrm{kha}^{32}$
$\mathrm{kaj}^{32}$
'galangal'
'chicken'
ma: ${ }^{32}$
'to soak rice'

Tone 4 represents a high-falling pitch with glottal constriction (42?).

$\begin{array}{ll}\text { kha: }{ }^{42 ?} & \text { 'to kill' } \\ \text { pha: }^{42 ?} & \text { 'cloth' } \\ \text { ha: }^{42 ?} & \text { 'five' }\end{array}$

This tone also occurs in a checked syllable as in the following words.

$\begin{array}{ll}\mathrm{kha}: \mathrm{t}^{42} & \text { 'to be torn' } \\ \mathrm{ka}: \mathrm{t}^{42} & \text { 'cabbage' } \\ \mathrm{Pa}: \mathrm{p}^{42} & \text { 'to bath' }\end{array}$

Tone 5 represents a high-level pitch with glottal constriction (44?).

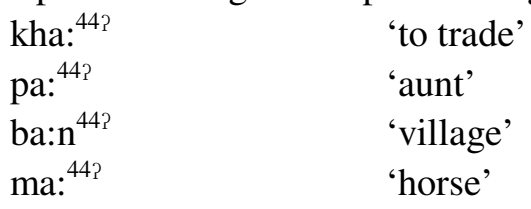




$$
\text { na:m } \mathrm{m}^{443} \quad \text { 'water' }
$$

This tone also occurs in a checked syllable as in the following words.

$\begin{array}{ll}\text { kha: } \mathrm{t}^{44} & \text { 'harrow' } \\ \text { ha:k } \mathrm{k}^{44} & \text { 'root' } \\ \mathrm{l} \text { i at }{ }^{44} & \text { 'blood' }\end{array}$

Consonants. There are 20 consonants. These can occur in the syllable initial position i.e. : $p$ $p h-b$ - $t$ - $t h-d-c-k-k h-?-f-s-h-m-n-n-\eta-l-w-j$ - and some of them can occur in the syllable final position : $-p-t-k-?-m-n-\eta-w-j$. Their phonetic characteristics are as follows:

$/ \mathrm{p} /$ represents a voiceless unaspirated bilabial stop [p] when it occurs as an initial consonant, and it is inaudibly released $\left[\mathrm{p}^{\urcorner}\right]$when it occurs as a final consonant.

$\begin{array}{ll}\text { pa: }^{32} & \text { 'forest' } \\ \text { pi }^{33} & \text { 'year' } \\ \text { pa: }:{ }^{43} & \text { 'aunt' } \\ \text { p :p }{ }^{42} & \text { 'ogress' }\end{array}$

$/ \mathrm{ph} /$ represents a voiceless aspirated bilabial stop $\left[\mathrm{p}^{\mathrm{h}}\right]$. It occurs in the syllable initial position only.

$\begin{array}{ll}\text { pha: }^{32} & \text { 'to split' } \\ \text { phaw }^{33} & \text { 'chubby as a child' } \\ \text { phi: }^{24} & \text { 'ghost' }\end{array}$

/b/ represents a voiced unaspirated bilabial stop with pre-glottalization [?b]. It occurs in the syllable initial position only.
ba: ${ }^{32}$
ba: $n^{443}$
'shoulder'
ba: $w^{32}$
'village'
'young man'

/ $t$ / represents a voiceless unaspirated alveolar stop [t] when it occurs as an initial consonant, and it is inaudibly released [ $\mathrm{t}\urcorner]$ when it occurs as a final consonant.
$\mathrm{ta}^{32}$
$\tan ^{32}$
'small basket'
'small stool'
'to cut'

$/$ th/ represents a voiceless aspirated alveolar stop $\left[\mathrm{t}^{\mathrm{h}}\right]$. It occurs in the syllable initial position only.

$$
\begin{array}{ll}
\text { tha: }^{32} & \text { 'dock' } \\
\text { thay }^{32} & \text { 'to strike' }
\end{array}
$$

/d/ represents a voiced unaspirated bilabial stop with pre-glottalization [?d]. It occurs in the syllable initial position only.

$$
\begin{array}{ll}
\text { da: }{ }^{32} & \text { 'to scold' } \\
\text { day }^{33} & \text { 'nose' }
\end{array}
$$

/c/ represents a voiceless unaspirated alveolo-palatal affricate [t6]. It occurs in the syllable initial position only.
caj $^{33}$
'heart'
ca: $\eta^{33}$
'insipid' 
$/ \mathrm{k} /$ represents a voiceless unaspirated velar stop [k] when it occurs as an initial consonant, and it is inaudibly released $\left[\mathrm{k}^{\urcorner}\right]$when it occurs as a final consonant.
$\mathrm{kaj}^{33}$
$\mathrm{kaj}^{32}$
'far'
ka: $y^{33}$
'chicken'
$\mathrm{kok}^{35}$
'to spread'
'base'

$/ \mathrm{kh} /$ represents a voiceless aspirated velar stop $\left[\mathrm{k}^{\mathrm{h}}\right]$. It occurs in the syllable initial position only.
khaj $^{32}$
'egg'
kha: $\eta^{33}$
'chin'

/ $/$ / represents a glottal stop [?] when it occurs as an initial consonant, and it is inaudibly released $[?]]$ when it occurs as a final consonant.
$\mathrm{Paj}^{33}$
'to cough'
? मे $^{35}$
'pumpkin' (full word: ma: $\mathrm{k}^{42}$ ? i $^{35}$ )

/f/ represents a voiceless labiodental fricative [f]. It occurs in the syllable initial position only.
faj $^{33}$
'fire'
'boil, ulcer'

/s/ represents a voiceless alveolar fricative [s]. It occurs in the syllable initial position only.
$\mathrm{saj}^{33}$
'fish trap'
'three'

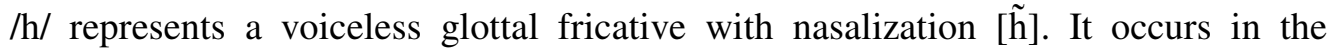
syllable initial position only.
haj $^{33}$
'chicken louse'
ha: $\mathrm{m}^{24}$
'to carry by two persons'

$/ \mathrm{m} /$ represents a voiced bilabial nasal [m]. It can occur both in the syllable initial position and in the syllable final position.
ma: ${ }^{33}$
'to come'
$\mathrm{ma}: \mathrm{m}^{44 ?}$
'spleen'

$/ \mathrm{n} /$ represents a voiced alveolar nasal [n]. It can occur both in the syllable initial position and in the syllable final position.

$\begin{array}{ll}\text { na: }^{33} & \text { 'rice field' } \\ \text { nom }^{33} & \text { 'milk' } \\ \text { nay }^{24} & \text { 'skin' } \\ \text { nว:n } & \text { 'to sleep' }\end{array}$

$/ \mathrm{n} /$ represents a voiced palatal nasal [n]. It occurs in the syllable initial position only.

$\begin{array}{ll}\text { na: }{ }^{32} & \text { 'grandmother' } \\ \text { ла: }{ }^{32} & \text { 'to walk' }\end{array}$

$/ \mathrm{y} /$ represents a voiced velar nasal [ $\mathrm{y}]$. It can occur both in the syllable initial position and in the syllable final position.

$\begin{array}{ll}\text { ya: }:^{32} & \text { 'tree branch' } \\ \text { ya: } & \text { 'sesame' } \\ \text { ya:y } & \text { 'twig' }\end{array}$


/1/ represents a voiced alveolar lateral approximant [1]. It occurs in the syllable initial position only.
$1 \mathrm{lom}^{33}$
$\operatorname{lan}^{24}$
'wind'
'back'

/w/ represents a voiced labio-velar approximant [w]. It can occur both in the syllable initial position and in the syllable final position.
wa: ${ }^{33}$
'linear measure of 2 meters'
wi: ${ }^{33}$
'to fan'
wa: ${ }^{32}$
'kite'

/j/ represents a voiced palatal approximant [j]. It can occur both in the syllable initial position and in the syllable final position.
ja: $:^{33}$
$\mathrm{ja}{ }^{32}$
'medicine'
'do not'
$\mathrm{ja}: \mathrm{j}^{33}$
'to place something in order'

Vowels. There are 18 monophthongs : $i$ i: e e : $\varepsilon$ $\varepsilon: \dot{t} \dot{t}:$ ə ə: $и$ u: $о$ o: $\supset$ ว: and three diphthongs : ia $\dot{t}$ a $u$. Their phonetic characteristics are as the following.

/i/ represents a short close front vowel [i] but it is slightly more open than Cardinal vowel 1.

$$
\operatorname{khin}^{24} \quad \text { 'ginger' }
$$

/i:/ represents a long close front vowel [i:] but it is slightly more open than Cardinal Vowel 1.

$$
\begin{array}{ll}
\text { khi: } \eta^{33} & \text { 'body' } \\
\text { pi:n } & \text { 'to turn upside down' }
\end{array}
$$

/e/ represents a short close-mid front vowel [e] but it is slightly more open than Cardinal Vowel 2.

$$
\begin{array}{ll}
\operatorname{Pen}^{33} & \text { 'tendon' } \\
\operatorname{hen}^{24} & \text { 'to see' } \\
\operatorname{ken}^{32} & \text { 'smart' }
\end{array}
$$

/e:/ represents a long close-mid front vowel [e:] but it is slightly more open than Cardinal Vowel 2.
Pe: $n^{33}$
le: $\mathrm{n}^{24}$
'to lie down'
'great grandson'

$/ \varepsilon /$ represents a short open-mid front vowel [E] but it is slightly more open than Cardinal Vowel 3.
$k \& \eta^{32}$
$\mathrm{b} \varepsilon \mathrm{y}^{32}$
'to swing'
'to divide'

$/ \varepsilon: /$ represents a long open-mid front vowel [ $\varepsilon:]$ but it is slightly more open than Cardinal Vowel 3.
$k \varepsilon: n^{33}$
khe: $\mathrm{y}^{32}$
'curry'
'shin'
$/ \mathfrak{i} /$ represents a short close central vowel $[\dot{i}]$.

$$
\min { }^{33} \text { 'dizzy' }
$$




$$
\operatorname{khin}{ }^{24} \quad \text { 'to stretch' }
$$

$/ \mathrm{i}: /$ represents a long close central vowel [i:].

$$
\begin{array}{ll}
\mathrm{mi}: \mathrm{n}^{33} & \text { 'to open (one's) eyes' } \\
\mathrm{ti}: \mathrm{m}^{32} & \text { 'to add' }
\end{array}
$$

/ə/ represents a short open-mid central vowel [ə].

$$
\begin{array}{ll}
\mathrm{l}^{33} & \text { 'deep' } \\
\mathrm{kh}^{32}{ }^{24} & \text { 'a kind of fish trap' }
\end{array}
$$

/ə:/ represents a long open-mid central vowel [ə:].

$$
\begin{aligned}
& \text { lə: } \mathrm{k}^{44} \quad \text { 'scraped (skin)' } \\
& \text { thə: } \mathrm{k}^{42} \quad \text { 'to go bald' }
\end{aligned}
$$

/a/ represents a short open central vowel [e].

$$
\begin{array}{ll}
\operatorname{khan}^{24} & \text { 'to pen' } \\
\operatorname{lak}^{33} & \text { 'to steal' }
\end{array}
$$

/a:/ represents a long open central vowel [в:].

$\begin{array}{ll}\mathrm{kha}: \mathrm{y}^{24} & \text { 'to warm one's hands before fire' } \\ \text { tha: } \mathrm{k}^{42} & \text { 'to chip away' }\end{array}$

$/ \mathrm{u} /$ represents a short close back rounded vowel $[\mathrm{u}]$ but it is slightly more open than Cardinal Vowel 8.
num $^{33}$
cum $^{32}$
'mosquito'
'to dip'

/u:/ represents a long close back rounded vowel but it is slightly more open than Cardinal Vowel 8.

$$
\begin{array}{ll}
\text { nu: } y^{33} & \text { 'peacock' (full word }: \text { nok }^{33} \text { nu: } \mathrm{y}^{33} \text { ) } \\
\text { cu: } \mathrm{m}^{33} & \text { 'budding' }
\end{array}
$$

/o/ represents a short close-mid back rounded vowel [o] but it is slightly more open than Cardinal Vowel 7.

$$
\begin{array}{ll}
\operatorname{com}^{32} & \text { 'to repine' } \\
\operatorname{com}^{33} & \text { 'to sink' }
\end{array}
$$

/o:/ represents a long close-mid back rounded vowel [o:] but it is slightly more open than Cardinal Vowel 7.

$$
\begin{array}{ll}
\text { co: } \mathrm{m}^{33} & \text { 'to carry with two hands' } \\
\text { to: } y^{32} & \text { 'to collect water' }
\end{array}
$$

/Ј/ represents a short open-mid back rounded vowel [ə] but it is slightly more open than Cardinal Vowel 6.
$\mathrm{kh}^{\mathrm{j}}{ }^{42 ?}$
$\operatorname{ton}^{32}$
'I'
'bundle'

/っ:/ represents a long open-mid back rounded vowel [॰:] but it is slightly more open than Cardinal Vowel 6.

$\begin{array}{ll}\mathrm{kh} \supset: \mathrm{j}^{443} & \text { 'slope' } \\ \mathrm{c} \supset: \mathrm{m}^{33} & \text { 'peak' }\end{array}$


/ia/ represents a diphthong [i:a] when it occurs in a smooth syllable and a checked syllable. There is no short [ia].

$\begin{array}{ll}\operatorname{mia}^{33} & \text { 'wife' } \\ \operatorname{piak}^{42} & \text { 'wet' }\end{array}$

$/ \mathrm{i}$ a/ represents a diphthong $[\dot{i}: \mathrm{a}]$ when it occurs in a smooth syllable and a checked syllable. There is no short [ $\dot{\mathrm{i} a}]$.

$\begin{array}{ll}\mathrm{mia}^{33} & \text { 'to go back' } \\ \mathrm{piak} & \text { 'bark' }\end{array}$

/ua/ represents a diphthong [u:a] when it occurs in a smooth syllable and a checked syllable. It becomes short [ua] when it occurs in a checked syllable with final glottal stop [?].

$\begin{array}{ll}\text { mua }^{33} & \text { 'gloomy' } \\ \text { puak }^{42} & \text { 'white ant' } \\ \text { tuar }^{35} & \text { 'to deceive' }\end{array}$

